\title{
COSTLY INFORMATION IN FIRM \\ TRANSFORMATION, EXIT, OR \\ PERSISTENT FAILURE
}

Lynne G. Zucker

Michael R. Darby

Working Paper 5577

\section{NATIONAL BUREAU OF ECONOMIC RESEARCH 1050 Massachusetts Avenue \\ Cambridge, MA 02138 \\ May 1996}

This research has been supported by grants from the Alfred P. Sloan Foundation through the NBER Research Program on Industrial Technology and Productivity, the National Science Foundation (SES 9012925), the University of California Systemwide Biotechnology Research and Education Program, and the University of California's Pacific Rim Research Program. We are indebted to a remarkably talented team of post-doctoral fellows Zhong Deng, Julia Liebeskind, and Yusheng Peng and research assistants Jeff Armstrong, Rajesh Chakrabatri, Yui Suzuki, Akio Tagawa, Maximo Torero, and Alan Wang. This paper is part of NBER's research program in Productivity. Any opinions expressed are those of the authors and not those of the National Bureau of Economic Research.

(C) 1996 by Lynne G. Zucker and Michael R. Darby. All rights reserved. Short sections of text, not to exceed two paragraphs, may be quoted without explicit permission provided that full credit, including (C) notice, is given to the source. 


\title{
COSTLY INFORMATION IN FIRM \\ TRANSFORMATION, EXIT, OR PERSISTENT FAILURE
}

\begin{abstract}
$\underline{\text { ABSTRACT }}$
Firms invest differentially in the intellectual human capital required to recognize, evaluate, and utilize technological breakthroughs occurring outside the firm. Such differential investment has been crucial in explaining which incumbent pharmaceutical firms have successfully transformed their technological identities in response to the biotechnological revolution and which are threatened by persistent low performance. While all incumbent firms lagged the dedicated new biotechnology firms in adopting the new drug-discovery technology, firms with higher R\&D expenditures before the biotech revolution were more likely to successfully adopt the new techniques and likely to do so earlier. Failure to adopt the new techniques was associated with lower performance compared to firms adopting more fully and faster.
\end{abstract}

Lynne G. Zucker Department of Sociology University of California, Los Angeles Los Angeles, CA 90095-1551 and NBER
Michael R. Darby

Anderson Graduate School of Management University of California, Los Angeles

Los Angeles, CA 90095-1481 and NBER 


\section{Costly Information in Firm Transformation, Exit, or Persistent Failure Lynne G. Zucker and Michael R. Darby, UCLA}

It must be remembered that there is nothing more difficult to plan, more doubtful of success, nor more dangerous to manage than the creation of a new system .... The hesitation arises ... from the general skepticism of mankind which does not really believe in an innovation until experience proves its value.

-- Niccolo Machiavelli, The Prince, p. 15, lines 62-72.

When information needed to make "smart" decisions about adoption and implementation of innovation is costly to obtain, to evaluate, or to utilize, we expect that firms will vary significantly in the amount of information they are willing to invest in acquiring or using (Darby 1976). To acquire and use information, including estimating its value to the firm, specific intellectual human capital, or at least access to specific intellectual human capital, may be necessary (Zucker 1991).

In the case of scientific breakthrough innovations, those with the most information about these discoveries are the scientists actually making them. This information constitutes intellectual human capital retained by the discovering scientists (Zucker, Darby, and Brewer 1994). Few scientists know the new techniques, it takes considerable time for other scientists to learn the techniques in the laboratories of the discovering scientists (as collaborators or as graduate and postdoctoral students), and hence there is transient scarcity of this embodied know-how at the time of a major breakthrough in science (Zucker, Darby, and Brewer 1994; Zucker, Darby, and Armstrong 1994). ${ }^{1}$ When these discoveries have immediate commercial value, as in the cases of 
semiconductors and biotechnology (Teitelman 1994), the discovering scientists have commercially valuable information which is initially very costly for others to obtain.

Incumbent pharmaceutical firms with substantial assets are motivated to redeploy these assets to perform effectively under changed circumstances (Zucker and Darby 1995a). Unlike other industries in which firms become "permanently failing" such as electric railways--due in part to heavy sunk costs in assets that are difficult to redeploy (Meyer and Zucker 1989; Hilton and Due 1964), many pharmaceutical firms had high levels of investment in intellectual human capital at the time of the breakthrough discoveries and were able to successfully redeploy these assets either by retraining the scientists or by replacing those resistant to the new techniques (Zucker and Darby 1995a).

Incumbent firms continue this transformation process. A recent article on SmithKline Beecham's R\&D chief, George Poste, explores his attempts to turn around a company that is now the 10th largest in drug revenues, down from 3rd in 1989 (Flynn, March 4, 1996:81): "Poste [hired] 'bio-informaticians,' who are equipped with powerful computers to help locate genes by searching for patterns in DNA sequences .... Since becoming boss, he has cut the R\&D organization by nearly a quarter, axing 1,300 people who he felt were redundant or had not signed on to his vision."

Our theory is simple. Obtaining, evaluating, and using breakthrough discoveries in science rests on information that is costly: (1) To obtain and evaluate the information, prior investment in science is required; (2) To obtain access to tacit knowledge of top scientists making these discoveries, trust is generally necessary as intellectual property cannot be formally protected at early stages of discovery (Zucker and Darby 1995b; Zucker, Darby, Brewer, and Peng 1996); and (3) To use the information requires major redeployment of assets with significant downside risk 
if the discovery fails to produce the promised results or produces unexpected results (e.g., new product liability problems). These generalizations hold true at the level of the individual scientist, the university department, and the firm; in general, those individuals and organizations who enter a new scientific arena risk less or are less risk averse than those that do not.

The amount of accumulated assets prior to the innovation creates a paradoxical effect: those with more assets are unlikely to waste them by refusing to transform in the face of a superior innovation, but because they have more at risk and/or because of systematic biases toward overestimating downside risk under uncertainty (Tversky and Kahneman 1974), those with more assets are likely to lag behind those with less assets, waiting to see the revealed benefits. Once they do adopt, their higher level of accumulated assets may enable them to "catch up" to the early adopters. To apply these ideas directly to incumbent pharmaceutical firms, those with strong prior R\&D are expected to adopt recombinant DNA techniques and to become actively involved in producing biological-based drugs, but also expected initially to lag significantly behind the new start-up firms.

\section{Investment in Information Seeking and Evaluation by Incumbent Firms}

We expect differential abilities to detect, to evaluate, and to implement performanceenhancing innovations depending in part on the investment firms have made in intellectual human capital in the past. ${ }^{2}$ This investment not only has the virtue of improving identification of innovation, firms also have a wider range of choices about potential strategic alternatives that otherwise may exist in the firm's environment without being detected. Once choices are identified, this same intellectual human capital can be employed to evaluate, discriminating between innovations that are likely to improve firm performance if adopted, and those that are 
not likely to do so.

In Table 1, the world's leading firms in drug development are listed in order of the number of R\&D drugs in 1981-82, and their investment in intellectual human capital is indicated by their research intensity, measured by $R \& D$ expenditures and these expenditures per employee. For the U.S. firms with R\&D expenditure data broken out for 1984 , we can see that contemporary performance in terms of producing new drugs, here chemical compounds, is not particularly related to investments in intellectual human capital/information detection and evaluation made by these firms. The firm ranked second in the world, Bristol-Meyers, has relatively low research intensity compared to Merck, Upjohn, and Eli Lilly. American Home Products, ranked fifth, has the lowest research intensity, falling below even Warner-Lambert that is ranked 19th out of twenty firms world-wide.

It seems likely, then, that it is not simply profitability that leads to the decision to invest in information gathering and evaluation via intellectual human capital, but rather that investing and maintaining information systems for innovations reflects higher expectations of the frequency and importance of change in the industry, here specifically science-driven technological change. Thus it is the size and intensity of the R\&D effort, not the characteristics of the firm itself, that should predict whether firms will take the next strategic steps to decide whether or not to actually discover/engineer new biologicals itself, to become involved in other aspects of biologicals production such as manufacturing or marketing, and/or to invest in firms that are involved in biologicals in some way. Firms that invest more in these intellectual human capital-based detection and evaluation systems are likely to respond earlier and more effectively to the transformation in drug discovery and formulation caused by the genetic engineering revolution.

But mechanisms to gather information are real investments and incur costs even during 
periods when innovations become less frequent--thus, as innovations increase in both frequency and importance, more information gathering mechanisms will be associated with improved performance (on average); as innovations decrease on those dimensions, fewer information gathering mechanisms will be associated with improved performance (less sunk cost). To the extent that the demand for information is highly variable, or within-firm information risks systematic bias from internal politics as in performance evaluation of professionals, it will tend to be subcontracted out rather than built up within the firm (Darby 1976; Hanson 1995; Zucker 1991). For example, the leading incumbent pharmaceutical firms have long invested in relationships with top scientists, both as consultants and as recipients of funding for basic research (e.g., the original discovery of DNA) even during periods of low discovery rates in basic science; these scientists can be thought of as subcontractors to detect significant changes in basic science that might prove relevant to the firms.

We believe that similar processes must be important in other industries. Examining the minicomputer, cement, and airline industries, Tushman and Anderson (1986) report that empirically technological breakthroughs can either increase or decrease the risks faced by incumbent firms according to whether the breakthroughs are initiated within or without the incumbent industry and, further, that these effects decrease over successive discontinuities. We would interpret these findings as reflecting whether the breakthroughs occur in fields of science or technology in which the incumbent firms find it rational to invest in intellectual human capital capable of recognizing and utilizing the breakthroughs. Where breakthroughs have already occurred they are more likely to choose to acquire such competence and hence will be less threatened by successive breakthroughs. 


\section{National Levels in Bioscience \& Firm Ties to Intellectual Human Capital}

While information seeking and evaluation is a necessary condition to internal transformation, it is not sufficient: Incumbent firms must decide to employ or otherwise access intellectual human capital that embodies the new breakthrough technology (Zucker, Darby, and Brewer 1994; Zucker, Darby and Armstrong 1994). Both the tacit nature of this knowledge at the beginning of the breakthrough period and the demand for trust to protect valuable scientific discoveries make working relationships with scientists necessary.

Two kinds of working relationships appear to be the most common methods: top scientists moving from universities to firms ("affiliated") or conducting joint research projects at the bench science level between these "star" discovering scientists, many of whom remain at the university, and scientists working at the firm ("linked"). We identify a subset of these relationships that occur between the world-wide "star" bioscientists, those with over 40 genetic sequence discoveries or 20 articles reporting such discoveries by 1990 in GenBank, and firms (Bilofsky and Burks 1988; GenBank September 1990). Increases in intensity of these working scientific relationships, as measured by the number of joint research articles between affiliated or linked "star" scientists and other firm scientists, results in significantly higher firm productivity, at least for linked stars in our initial empirical test limited to California (Zucker, Darby, and Armstrong 1994).

Star scientists are not evenly distributed across the world, but depend on the size of the scientific base and supporting scientific infrastructure in bioscience in each of the countries. Table 2 shows the general distribution, with the U.S. clearly dominant and Japan second, though Japan has only about half of the expected stars based on a straight population-base prediction when compared to the U.S. Similarly, Germany and France also have about half of the expected 
stars relative to the U.S.; the U.K. looks somewhat stronger, though if the net out-migration of star bioscientists is taken into account (see tables in Zucker and Darby 1996a and 1996b) then the findings echo Japan, Germany, and France.

Ties to firms (including both affiliated and linked) vary even more strikingly across countries. The third column in Table 2 shows that a higher percentage of stars in Japan are ever "tied" (affiliated or linked) to firms than in the U.S., while less than a third as many stars are tied to firms in the U.K. and none in France and Germany.

Most of the firms are pharmaceutical firms or small, new biotechnology firms. One measure of the intensity of their scientific research is their R\&D expenditures per employee. So in Table 2 we continue our analysis by examining changes over time in R\&D expenditures and labor compensation per employee in drugs for the four countries where data are available (Danzon and Percy 1995). Relative to the U.S., in 1981 drug firms in Germany spent about three quarters as much on R\&D per employee, while the level of spending was about two-thirds in France and the U.K. Relative spending dropped across the board to about half of U.S. levels by 1990, dropping rather precipitously between 1985 and 1990 in Germany. Labor compensation in 1975 relative to the U.S. was hovering at about three quarters for France and Germany, and about half for the U.K.; by 1990 , France had risen to $86 \%$ of the U.S. level, while the U.K. had risen to over three quarters. Germany declined slightly in labor compensation relative to the U.S.

Not shown in Table 2 is what was happening to the levels of R\&D spending in the pharmaceutical industry in the U.S.: By 1987, the average drug R\&D per employee in the U.S. had nearly doubled its 1981 value, and it continued its steady climb, up another 40 percent by 1990. Much of the increase in the U.S. was due to the new biotechnology firms that continued to make heavy $R \& D$ investments relative to other pharmaceutical companies; while the biotech 
industry made on average a $23 \%$ increase in R\&D between 1993 and 1994 , the leading incumbent pharmaceutical company, Merck, made only a 9\% increase between 1992 and 1993 (Ernst \& Young 1994: Figure 1).

\section{Lag by Incumbent Firms in Ties to Stars and in Genetic Sequence Patents}

Since incumbent firms face greater downside risk than new biotech start-ups, we expect that they will lag behind the new firms in their use of the breakthrough techniques. We have analyzed the pattern of both ties to star scientists and patenting over time for U.S. firms, comparing incumbent pharmaceutical firms to new biotechnology firms.

Table 3 compares the history of ties between stars and firms by examining publication counts of affiliated or linked stars over time between dedicated biotech firms, major incumbent firms, and other incumbent subunits. In other research we have found that the number of publications in these bench-level working relationships predicted higher subsequent firm productivity in terms of products in development, products on the market, and employment growth in the firm (Zucker, Darby, and Armstrong 1994). Thus, firms with access to leading edge science as evidenced by such affiliations and linkages perform significantly better than the vast majority of enterprises which lack such access.

We examine the intensity of ties between stars and firms for the periods 1976-1980, 1981$1985,1986-1990$ in Table 3. During the first five years of the biotech revolution only one wellknown new biotechnology firm had the intellectual human capital which we are measuring here. In the second five years, 17 firms had demonstrated substantial access to intellectual human capital of which almost 24 percent were major pharmaceutical firms and the remainder were new biotechs. Quantitatively, the pharmaceuticals lagged further, however, with all 97 articles by 
affiliated stars being published by stars affiliated with new biotech firms and only 19 percent of 52 linked articles linked to pharmaceutical firms.

In the third five-year period 1986-1990 summarized in Table 3 there appears to be evidence of a general catch-up effort by pharmaceutical firms. Pharmaceutical firms began to have star scientists publishing as their employees (11 percent) and their share of linked articles rose to 24 percent (excluding the nascent group of incumbent firms in other industries with significant scientific capital).

In Table 4 we see a similar pattern of results in the area of patent production. However, the timing is somewhat later: while the science diffused rapidly in the late 1970s in terms of initial publications of stars, patenting of genetic sequences did not boom until the mid 1980s in the U.S. GenBank has data on 3353 patents granted through the end of 1990 , of which we were able to link 611 or 18.2 percent of the world total to 21 of the 34 firms examined in Table $3 .^{3}$ Table 4 provides annual data for total numbers of genetic-sequence patents granted to the major pharmaceuticals with ties to stars, to the corresponding NBFs, and their sum. For purposes of rough comparisons to Table 3, we again add the values for 1980-1985, 1986-1990, and 19801990. Again, we find that the major pharmaceuticals lagged behind the dedicated biotech firms but then began catching up quickly in the late 1980s: they had only 8.7 percent of total patents for $1980-1985$, but this rose to 21.3 percent in $1986-1990$. Given an average lag of perhaps two years between application and granting of the patent, this performance is even more remarkable.

As we have shown, though the incumbent pharmaceutical firms are closing the gap in the U.S., even the most transformed incumbent firms still lag the new biotechnology firms in detection, evaluation, and use of the breakthrough discoveries. To assess the effects of these lags, we examine the performance of incumbent firms relative to the new biotechnology firms in drug 
discovery in biologicals, examining biological drugs receiving FDA (Food \& Drug Administration) approval on the market in the U.S. through 1994, and then turn to a more general comparison of overall performance of world-wide pharmaceutical firms judged most productive in 1981 , adding in the new biotech firms with products on the market by the end of 1993 .

\section{Effects on Productivity of the Firm}

In Zucker and Darby (1995a), we identified nine major American incumbent pharmaceutical companies which appeared by 1990 to be successful in transforming their technological identity in drug discovery to biotechnology. These firms were identified on the basis that one or more star scientists were working as or with employees of the firm and that the firm was assigned patents for genetic-sequence discoveries. Based on other work (Zucker and Darby 1996a), we expect this pattern to be associated with both more important research on the part of the star scientists themselves and with greater firm success as measured by numbers of products in development and on the market and by growth in employment.

If we are correct that this is a dominant technology, then we would expect that these nine firms would have done relatively well in recent years compared to those with no evidence of successful transformation. By and large, this is borne out by the firms' experience in the first half of the 1990s. By the end of 1995 , despite a wave of consolidation in the pharmaceutical industry five of the firms continued as successful major American pharmaceutical firms with no change in control (although some of them had themselves made significant acquisitions). ${ }^{4}$ Another firm's major pharmaceutical operations were transferred to a joint venture formed by its chemical-company parent and one of the five firms just mentioned. ${ }^{5}$ One of the remaining three firms merged into a major European pharmaceutical firm which itself had successfully 
transformed to biotechnology, and the merged firm is one of the world's leaders in biotech. ${ }^{6} \mathrm{~A}$ second entered into a merger with a European firm with the resulting firm's ownership equally divided by the stockholders of the two merging firms. ${ }^{7}$ Control of the last firm was acquired by one of the other major European pharmaceutical groups, but it remains a separate American enterprise with substantial public ownership. ${ }^{8}$ The biotechnological research thrust of the entire group is built around the American corporation.

To explore the net effect of strategic decisions by firms on their productivity in producing and/or licensing, manufacturing, or marketing new biologicals, and on the overall productivity of these firms, we now turn to a comparison among major incumbent pharmaceutical firms worldwide, as identified in Table 1 above. In Tables 3 and 4 , we have documented systematic differences in the strategies concerning adoption of new breakthrough technology by incumbent pharmaceutical firms and by new biotechnology firms in the U.S. Incumbent pharmaceutical firms lag in adoption, but also show their ability to redeploy their assets effectively and quickly once they judge that the value of the breakthrough discoveries has been established.

In Table 5 we examine the 18 companies which obtained licenses for the first 21 new biological entities licensed for U.S. marketing as well as the other companies from Table 1. There is considerable diversity of experience among the companies listed in Table 1. Among the 20 leading companies identified in 1981-1982, only 9 had any new biological entities licensed for U.S. marketing by $1994-7$ if we exclude the 2 with biologicals only because of late acquisitions of dedicated biotech companies. One more preexisting pharmaceutical company and 7 other dedicated biotech companies complete the list bringing products of the new technology to market.

Also in Table 5, subsidiaries and majority-owned firms with licensed biologicals are 
indented below their parents. In the case of Chiron, Genentech, and Genetics Institute, this ownership or control was acquired after their first new biological entities in the table were licensed for U.S. marketing. Clearly, a strategy that we have only briefly mentioned--adopting the breakthrough discoveries primarily through purchase of one or more dedicated biotech firm-was also actively pursued. Note that the incumbent firms who did not have star bioscientists tied to them through affiliation or linkage were more likely to acquire a dedicated biotechnology firm.

Some firms are quite successful relative to their competitors, sometimes in drug discovery, other times in licensing, manufacturing, and marketing these new discoveries. In Table 6 we can see the striking effects. Actively "downsizing" in both R\&D and manufacturing in 1995-96 were the former power-house, Hoechst, and recent mergers included Upjohn. Others have failed, such as American Cyanamid that was acquired by American Home Products, and although only 20 years out from the founding of Genentech, others already appear to be on their way to permanently failing status.

Boehringer-Ingelheim, Rhône-Poulenc, Bayer, Dow-Chemical, SmithKline Beecham, Baxter, and of course Hoechst all have low performance relative to the top firms. Clearly, the order of top performing pharmaceutical firms has been profoundly disturbed by the genetic revolution. Of the new dedicated biotech firms, the ones that are profitable have largely been acquired as they required more capital than they were able to raise by other means (with the major exception being Amgen); other new firms still talk primarily in terms of the "burn rate" of their capital, and some continue to show strongly negative earnings as a percent of sales.

\section{Summary and Implications}

Preference for science-based drug discovery is revealed in both the amount and percentage 
devoted to R\&D functions of the firm. Incumbent firms in the U.S. and elsewhere with such preferences are more likely to invest in top scientists at the leading edge of the breakthrough discoveries, and to move to capture quickly, through patenting or other means, the intellectual property created. National research funding policy conditioned the number of top scientists available at the time of the breakthrough, and the subsequent speed of ramp up as the importance of the breakthrough was recognized.

Within the U.S., incumbent firms were slower to commercialize these new discoveries than new biotechnology firms, in part because the breakthroughs were made in California universities that had heavily invested in molecular biology and the major incumbent pharmaceutical firms were located primarily in New Jersey and surrounding states. Little or no-and to a lesser extent slow--use of the breakthrough discoveries resulted in generally lower performance compared to those firms who adopted more fully and faster. Few large incumbent firms actually went out of business during the twenty years since commercialization began, but many merged or became low performing. As we begin to unravel the process of transferring scientific discovery to the firm, we also tell the story of the profound effects that basic science in a span of 20 years has wrought in a major international industry. The lag generated by downside risk to firms with significant assets has a telling effect, but whether that effect is permanent for incumbent firms depends on whether or not they are willing to make the transition to the new technology, and the strategy of conversion that they choose. The rest of our story has yet to be written, but given the costly information problem, we expect that incumbent firms who choose to incorporate the new discoveries internally will be more successful in identifying, evaluating, and using the next major breakthrough discovery and continuing to prosper with new radical changes in technological regime. 


\section{FOOTNOTES}

1.This is not simply "tacit knowledge," but rather knowledge that has initial tacit properties that may or may not remain as the knowledge becomes routinized as "normal science."

2.Firms are not motivated to seek information about innovations unless innovations have occurred with a high degree of frequency and were often important in improving performance in the past. Thus the past is prologue in the sense of making rational certain investments in information gathering.

3. We matched genetic-sequence patents to 8 of the 9 major pharmaceutical firms, 13 of the 22 dedicated biotech firms, but found no genetic sequence patents for the 3 other NBSs. Of course, the latter group were late on the scene and may appear in patent data after the 1990 cutoff in the data which we have so far analyzed.

4. Abbott Laboratories, Schering-Plough (DNAX Research Institute subsidiary), Eli Lilly and Co., Merck \& Co., and Monsanto Company (G.D. Searle subsidiary).

5. E.I. Du Pont, Biotechnology Systems formed joint venture with Merck \& Co. called Du Pont Merck Pharmaceuticals Co. (January 1991).

6. SmithKline Beckman merged into Beecham Group plc to form SmithKline Beecham plc (July 1989).

7. Upjohn Co. merged fall 1995 with Pharmacia AB of Sweden to form Pharmacia \& Upjohn, Inc. (a Delaware Corp. based in London and traded in New York, London, and Stockholm). 8. In August 1990 Rhône-Poulenc Group merged its human pharmaceutical business with the Rorer Group which was renamed Rhône-Poulenc Rorer, Inc. The Rhône-Poulenc Group holds about $68 \%$ ownership in Rhône-Poulenc Rorer, Inc., with the remaining 32\% of the shares trading on the NYSE. The Rhône-Poulenc Group has a strong, independent presence in veterinary and agricultural applications of biotechnology. 


\section{REFERENCES}

Bilofsky, H.S., and C. Burks, "The GenBank (R) Genetic Sequence Data Bank, "Nucleic Acids Research, 1988, 16: 1861-1864.

Bioscan, various issues, 1988-1995.

California Department of Commerce, Drugs and Pharmaceuticals, Report R-66A, prepared by the Institute for the Future, Sacramento, CA: California Department of Commerce, May 1986.

Damanpour, Fariborz (1991). Organizational Innovation: A Meta-Analysis of Effects of Determinants and Moderators. " Academy of Management Journal 34:555-90.

Danzon, Patricia M., and Allison Percy (1995) "The Effects of Price Regulation on Productivity in Pharmaceuticals, " paper presented at the NBER Summer Institute on Productivity, Cambridge, MA, July 28.

Darby, Michael R. (1976) "Rational expectations under conditions of costly information." The Journal of Finance 31(3, June): 889-895.

Flynn, Julia (1996) [with John Carey, Joseph Weber, and Joan O'C. Hamilton] "Is SmithKline's Future in its Genes? R\&D chief Poste is racing ahead in gene-based drugs." Business Week March 4, 1996: 80-81.

GenBank, Release 65.0, machine readable data base, Palo Alto, CA: IntelliGentics, Inc., September 1990.

Hanson, Gordon H. (1995) "Incomplete Contracts, Risk, and Ownership, "International Economic Review 36(2, May): 341-65. 
Hilton, George W. and John F. Due (1964) The Electric Interurban Railways in America. Stanford, CA: Stanford University Press.

Lee, Kenneth B., Jr., and G. Steven Burrill, Biotech 95: Reform, Restructure, Renewal, Ernst \& Young Ninth Annual Report on the Biotechnology Industry, Ernst \& Young, 1995.

Machiavelli, Niccolo (1947) The Prince. Translated and edited by Thomas G. Bergin, Yale University. Arlington Heights, Ill: Harlan Davidson, Inc.

Meyer, Marshall W. and Lynne G. Zucker (1989) Permanently Failing Organizations. Newbury Park: Sage.

Moody's Investors Service, Inc., Moody's Industrial Manual 1988, New York, NY: Moody's Investors Service, Inc., 1988.

Moody's Investors Service, Inc., Moody's International Manual 1988, New York, NY: Moody's Investors Service, Inc., 1988.

Moody's Investors Service, Inc., Moody's OTC Industrial Manual 1988, New York, NY: Moody's Investors Service, Inc., 1988.

Moody's Investors Service, Inc., Moody's Industrial Manual 1995, New York, NY: Moody's Investors Service, Inc., 1995.

Moody's Investors Service, Inc., Moody's International Manual 1995, New York, NY: Moody's Investors Service, Inc., 1995.

Moody's Investors Service, Inc., Moody's OTC Industrial Manual 1995, New York, NY: Moody's Investors Service, Inc., 1988.

Nikkei Biotechnology, 94/95 sekai no baio kigyo 2000-sha ['94/'95 World's 2000 Bioindustry Corporations], Tokyo, Japan: Nikkei Business Publications, 1994. 
Pharmaceutical Manufacturers Association, "1993 Survey: 143 Biotechnology Medicines in Development, " in Price, Harvey S., and Roderick Greenshields, eds., The Biotechnology Report 1993/94, Hong Kong: Campden Publishing Ltd., 1993.

Porter, Michael E. (1985) Competitive Advantage: Creating and Sustaining Superior Performance. New York: Free Press.

Teitelman, Robert (1994) Profits of Science: The American Marriage of Business and Technology. New York: Basic Books/Harper Collins.

Tushman, Michael L., and Philip Anderson (1986) "Technological discontinuities and organizational environments. " Administrative Science Quarterly 31 (March):439-465.

Tversky, Amos and Daniel Kahneman (1974) "Judgment under uncertainty: Heuristics and biases." Science 185 (September):1124-1131.

Zucker, Lynne G. (1991) "Markets for bureaucratic authority and control: Information quality in professions and services." Research in the Sociology of Organizations, 8:157-190.

Zucker, Lynne G., and Michael R. Darby (1995a) "Present at the Revolution: Transformation of Technical Identity for a Large Incumbent Pharmaceutical Firm after the Biotechnological Breakthrough, " National Bureau of Economic Research Working Paper No. 5243, August. 
Zucker, Lynne G., and Michael R. Darby (1995b) "Sociological Analysis of Multi-Institutional Collaborations in Space Science and Geophysics. "Pp. 149-178 in Joan Warnow-Blewett, Anthony J. Capitos, Joel Genuth, and Spencer R. Weart, with contributions by Frederik Nebeker, Lynne Zucker, and Michael Darby, AIP Study of Multi-Institutional Collaborations, Phase II: Space Science and Geophysics. Report No. 2: Documenting Collaborations in Space Science and Geophysics, College Park, MD: American Institute of Physics.

Zucker, Lynne G., and Michael R. Darby (1996a) "Star Scientists and Institutional Transformation: Patterns of Invention and Innovation in the Formation of the Biotechnology Industry," Proceedings of the National Academy of Sciences, in press.

Zucker, Lynne G., and Michael R. Darby (1996b) "Star Scientist Linkages to Firms in APEC and European Countries: Indicators of Regional Institutional Differences Affecting Competitive Advantage, " International Journal of Technology Management, in press.

Zucker, Lynne G., Michael R. Darby, and Jeff Armstrong (1994) "Intellectual Human Capital and the Firm: The Technology of Geographically Localized Knowledge Spillovers, "National Bureau of Economic Research Working Paper No. 4946, December.

Zucker, Lynne G., Michael R. Darby, and Marilynn B. Brewer (1994) "Intellectual Human Capital and the Birth of U.S. Biotechnology Enterprises, " National Bureau of Economic Research Working Paper No. 4653, February.

Zucker, Lynne G., Michael R. Darby, Marilynn B. Brewer, and Yusheng Peng (1996) "Collaboration Structure and Information Dilemmas in Biotechnology: Organizational Boundaries as Trust Production." Pp. 90-113 in Roderick M. Kramer and Thomas Tyler, eds., Trust in Organizations: Frontiers of Theory and Research, Newbury Park, CA: Sage. 
Table 1

World's Leading Companies in the Development of New Drugs in 1981-1982 Analysis of Research \& Development Intensity

1984

\begin{tabular}{|c|c|c|c|c|}
\hline \multirow[b]{2}{*}{ Company } & \multirow[b]{2}{*}{ Country } & \multirow[b]{2}{*}{$\begin{array}{l}\text { Number of } \\
\text { R\&D Drugs }\end{array}$} & \multicolumn{2}{|r|}{1984} \\
\hline & & & $\begin{array}{l}\text { R\&D Expend } \\
(\$ \text { millions })^{a}\end{array}$ & $\begin{array}{l}\text { R\&D Exp./Employee } \\
(\$ \text { thousands) })^{\mathrm{a}}\end{array}$ \\
\hline Roche & Switzerland & 100 & & \\
\hline Bristol-Myers & United States & 82 & 214.2 & 6.3 \\
\hline Hoechst & Germany & 73 & & \\
\hline Merck \& Co. & United States & 72 & 396.0 & 11.8 \\
\hline American Home Products & United States & 66 & 184.6 & 0.4 \\
\hline Upjohn & United States & 64 & 264.0 & 12.0 \\
\hline Johnson \& Johnson & United States & 56 & 420.9 & 5.4 \\
\hline Eli Lilly & United States & 56 & 330.0 & 11.4 \\
\hline Ciba-Geigy & Switzerland & 49 & & \\
\hline Roussel-Uclaf & France & 48 & & \\
\hline Sandoz & Switzerland & 47 & & \\
\hline Boehringer-Ingelheim & Germany & 45 & & \\
\hline Rhône-Poulenc & France & 43 & & \\
\hline Bayer & Germany & 42 & & \\
\hline Schering-Plough & United States & 42 & 165.3 & 6.4 \\
\hline Meji Seika & Japan & 42 & & \\
\hline Dow-Chemical & United States & 41 & & \\
\hline Takeda & Japan & 41 & & \\
\hline Warner-Lambert & United States & 41 & 198.4 & 4.4 \\
\hline Beecham & Unit. Kingdom & 40 & & \\
\hline
\end{tabular}

Note: $\quad$ aesearch and Development expenditures for 1984 were not available for the nonU.S. firms and Dow-Chemical.

Source: California Department of Commerce (1986), Tables 11 and 12, and calculations by the authors. 
Table 2

The International Competitive Arena: Star Bioscientists' Commercial Involvement, R\&D Expenditures in Drugs per Employee, Employee Compensation in Drugs

Nation or

Region

United States

Japan

Other APEC

France

Germany

Switzerland

United Kingdom

Other Europe ${ }^{\mathrm{e}}$

Rest of world ${ }^{\mathrm{f}}$

Total World
Expenditures per Employee in Medicine \& Drugs Stars R\&D Expenditures ${ }^{a}$ Total $^{\mathrm{b}}$ Tied $^{\mathrm{c}}$ \%Tied 198

Total $^{\mathrm{b}}$ Tied $^{\mathrm{c}}$

Labor Compensation

$\begin{array}{llll}1975 \quad 1980 & 19851990\end{array}$

69

33.3

10

$52 \quad 21$

$24 \quad 1$

40.4

4.2

250

0.0

240

0.0

153

20.0

313

9.7

$30 \quad 3$

10.0

90

0.0

$417 \quad 100 \quad 24.0$

Notes: $\quad$ Indices relative to the United States deflated by GDP deflators and converted at purchasing-power-parity exchange rates.

${ }^{b}$ Unique stars ever publishing in a given country

cNumber of stars in the country who ever published as or with an employee of a NBE in the same country. For grouped entries, the sum of these numbers.

${ }^{d}$ Other APEC is Australia and Canada.

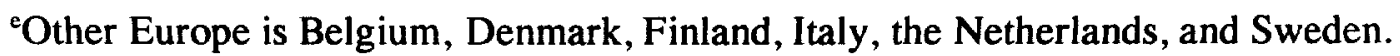
${ }^{\text {f }}$ Rest of world is Israel and the U.S.S.R.

Sources: Zucker and Darby (1996b), Table 3 and calculations of the authors; Danzon and Percy (1995), Tables 12c and 14. 
Table 3

Publications by Stars Affiliated with or Linked to U.S. Firms

Variables

No.

of

Firms

\begin{tabular}{lccc}
\multicolumn{4}{c}{ Publication Counts of Stars } \\
\hline Affiliated & Linked & Linked in & Linked \\
Stars & in BEA & other US & foreign $^{\mathrm{c}}$
\end{tabular}

1976-1980:

Dedicated Biotech Firms

Major Pharmaceutical Firms 0

9

0

0

0

0

Other Incumbent Subunits 0

Total for All Firms

1

0

0

0

$0 \quad 0$

9

0

0

0

1981-1985:

Dedicated Biotech Firms 13

$\begin{array}{rr}97 & 20 \\ 0 & 2 \\ 0 & 0\end{array}$

Major Pharmaceutical Firms 4

97

22

12

10

Other Incumbent Subunits 0

17

0

7

1

0

0

Total for All Firms

1986-1990:

Dedicated Biotech Firms 19

68

16

19

11

Major Pharmaceutical Firms 8

Other Incumbent Subunits 3

Total for All Firms $\quad 30$

$30 \quad 76$

8

3

30

6

$0 \quad 2$

9

4

20

Total for All Firms

21

41

10

1976-1990:

Dedicated Biotech Firms 22

Major Pharmaceutical Firms 9

Other Incumbent Subunits 3

Total for All Firms

$$
34
$$

174

36

42

16

85

16

5

0

2

2

182

43

60

21

'The firm's location and that of the university, research institute, or hospital with which the star is affiliated are in the same functional economic area as defined by the U.S. Bureau of Economic Analysis ("BEA").

${ }^{\mathrm{b}}$ The star is located in a university, research institute, or hospital in a different U.S. BEA.

-The star is located in a foreign university, research institute, or hospital.

Source: Zucker and Darby (1995a). 
Table 4

Worldwide Genetic-Sequence Patents Granted to U.S. Firms with Affiliated or Linked Stars 1980-1990

$\begin{array}{lccc}\text { Period } & \begin{array}{c}\text { Major } \\ \text { Pharmaceutical Firms }\end{array} & \begin{array}{c}\text { Dedicated Biotech } \\ \text { Firms }\end{array} & \text { All Firms } \\ 1980 & 0 & 2 & \\ 1981 & 0 & 4 & 4 \\ 1982 & 4 & 17 & 21 \\ 1983 & 0 & 9 & 9 \\ 1984 & 1 & 29 & 30 \\ 1985 & 4 & 34 & 38 \\ 1986 & 3 & 49 & 52 \\ 1987 & 10 & 18 & 28 \\ 1988 & 45 & 101 & 146 \\ 1989 & 43 & 152 & 195 \\ 1990 & 7 & 79 & 86 \\ 1980-85 & 9 & & 104 \\ 1986-90 & 108 & 95 & 507 \\ 1980-90 & & 399 & 611\end{array}$

Source: Zucker and Darby (1995a). 
Table 5 -- New Biological Entities Approved for the U.S. Market by 1994

\begin{tabular}{|c|c|c|c|c|c|c|}
\hline \multirow[b]{2}{*}{ Company $^{a}$} & \multirow[b]{2}{*}{ Country } & \multicolumn{2}{|c|}{ Year of $1 \mathrm{st}^{\mathrm{b}}$} & \multicolumn{2}{|c|}{ No. of Biologicals ${ }^{e}$} & \multirow{2}{*}{$\begin{array}{l}\text { Year(s) of F.D.A. } \\
\text { Approval of } \\
\text { Biologicals }\end{array}$} \\
\hline & & $\begin{array}{l}\text { Star's } \\
\text { Article }\end{array}$ & $\begin{array}{l}\text { Patent } \\
\text { in US }\end{array}$ & $\begin{array}{l}\text { Disco- } \\
\text { vered }^{c}\end{array}$ & $\begin{array}{l}\text { Lic., Mfg., } \\
\text { Marketed }^{\mathrm{d}}\end{array}$ & \\
\hline Roche & Switzerland & & & & & \\
\hline Hoffman-La Roche & & 89 & 86 & & 1 & 86 \\
\hline Genentech, Inc. & & 79 & 82 & 7 & & $82,85,86,87,89,90,93$ \\
\hline Bristol-Myers & United States & & 88 & & & \\
\hline $\begin{array}{l}\text { Hoechst } \\
\text { Roussel-Uclaf }\end{array}$ & Germany & & 89 & & & \\
\hline Merck \& Co. & United States & 87 & 86 & & 1 & 86 \\
\hline $\begin{array}{l}\text { American Home Products } \\
\text { Genetics Institute }\end{array}$ & United States & 84 & $\begin{array}{l}89 \\
88\end{array}$ & 1 & & 86 \\
\hline Upjohn & United States & 86 & 82 & & & \\
\hline $\begin{array}{l}\text { Johnson \& Johnson } \\
\text { Ortho Biotech Group }\end{array}$ & United States & & & 1 & 1 & 86,90 \\
\hline Eli Lilly & United States & 85 & 84 & 1 & 1 & 87,92 \\
\hline Ciba-Geigy & Switzerland & & 88 & & & \\
\hline Chiron (Cetus) & & 82 & 85 & 3 & & $86,92,93$ \\
\hline Sandoz & Switzerland & & & & & \\
\hline Boehringer-Ingelheim & Germany & & 88 & & & \\
\hline Rhône-Poulenc-Rorer & France/U.S. & 88 & 89 & & & \\
\hline $\begin{array}{l}\text { Bayer } \\
\text { Miles, Inc. }\end{array}$ & Germany & & $\begin{array}{l}90 \\
90\end{array}$ & 1 & & 93 \\
\hline Schering-Plough (DNAX) & United States & 82 & 87 & & 1 & 86 \\
\hline Meji Seika & Japan & & 88 & & & \\
\hline Dow-Chemical & United States & & & & & \\
\hline Takeda & Japan & 83 & 87 & & & \\
\hline Warner-Lambert & United States & & & & & \\
\hline Beecham & Unit. Kingdom & & & & & \\
\hline SmithKline Beecham & & 86 & 89 & & 1 & 89 \\
\hline Amgen & United States & & 88 & 2 & & 89,91 \\
\hline $\begin{array}{l}\text { Baxter International } \\
\text { Baxter Healthcare }\end{array}$ & United States & & & & 1 & 92 \\
\hline Berlex Biosciences & United States & 89 & & & 1 & 93 \\
\hline Biogen & United States & 83 & 85 & 1 & & 86 \\
\hline Cytogen & United States & & & 1 & & 92 \\
\hline Immunex & United States & & 88 & 1 & & 91 \\
\hline Interferon Sciences & United States & 83 & & 1 & & 89 \\
\hline Molecular Biosystems & United States & & & 1 & & 94 \\
\hline
\end{tabular}


Notes: a. Companies are those listed in the U.S. or their successor in the human therapeutics industry plus all other firms with new biological entities approved for marketing in the United States.

b. This data is currently available only through 1990 (the authors' relational data base described in Zucker, Darby, and Brewer 1994 and Zucker, Darby, and Armstrong 1994 is currently being updated through 1995). The "Star's Article" column gives the date of the first article (through 1990) authored by a star as or with an employee of the company. The "Patent in US" column gives the year of the first genetic-sequence patent in the United States assigned to the company.

c. These numbers are for new biological entities approved for marketing in the United States which were discovered at the firm regardless of whether they are manufactured and marketed directly by the firm or licensed to other firms.

d. These numbers are for new biological entities approved for marketing in the United States which were not discovered at the firm but are manufactured and/or marketed by the firm under license from another firm.

e. These companies may have new biological entities approved for marketing in their home or other markets but not in the United States which are not counted in this table.

Sources: $\quad$ Calculations by the authors; Lee and Burrill (1995), Pharmaceutical Manufacturers Association (1993). 
Table 6 -- Earnings as a Percent of Sales for Major Pharmaceutical Firms, 1987 and 1994

Company

Roche

Hoffman-LaRoche

Genentech, Inc.

Bristol-Myers Squibb

Hoechst

Roussel-Uclaf

Merck \& Co.

American Home Products Genetics Institute

Upjohn

Johnson \& Johnson

Ortho Biotech Group

Eli Lilly

Ciba-Geigy

Chiron

Sandoz

Boehringer-Ingelheim

Rhône-Poulenc Group

Bayer

Miles, Inc.

Schering-Plough

Meiji Seika Kaisha Ltd.

Dow-Chemical

Takeda

Warner-Lambert

Beecham

SmithKline Beecham

Amgen

Baxter International

Baxter Healthcare

Berlex Biosciences

Biogen

Biogen N.V.

Cytogen

Immunex

Natl. Patent Development Interferon Sciences

Molecular Biosystems
Country

Switzerland

United States

Germany

United States

United States

United States

United States

United States

17.7

Switzerland

3.6

16.1

7.0

Switzerland

Germany

France

Germany

United States

11.7

Japan

United States

Japan

United States

Unit. Kingdom

United States

$-10.4$

United States

United States

United States

United States

United States

United States

United States

6.5

$1.1^{*}$

9.3

$6.0^{*}$

8.5

9.6

$-180.7$

$-36.7$

$-1.6$

9.3

24.9 $\frac{\text { Earnings as a \% of Sales }}{1987}$ Source
19.4

15.6

15.4

2.8

11.2

20.0

17.0

$-14.4$

15.0

12.8

12.8

22.5

8.7

6.6

10.9

4.0

4.7

4.5

1.1

19.8

4.7

$6.5^{*}$

10.8

1.8

19.4

6.4

6.4

$\mathrm{n} / \mathrm{a}^{* *}$

$-3.1$

b

a

a

b

b

a

a

d

a

a

d

a

b

c

b

b

b

b

d

a

b

a

b

a

b

b

c

a

d

c

b

c

c

$-6.8 \quad a$

$\begin{array}{ll}-214.0 & c\end{array}$ 


\section{Notes for Table 6}

*Japanese fiscal year figures for April 1 of indicated year through March 31 of following year. **Privately held.

Sources: a. Moody's Industrial Manual 1988 and Moody's Industrial Manual 1995.

b. Moody's International Manual 1988 and Moody's International Manual 1995.

c. Moody's OTC Industrial Manual 1988 and Moody's OTC Industrial Manual 1995.

d. Bioscan, various issues, 1988-1995. 